\title{
FACTORS ASSOCIATED MOSQUITO LARVAE ERADICATION AND EARLY MANAGEMENT OF DENGUE HEMORRHAGIC FEVER AMONG POOR COMMUNITY IN LOKAPAKSA VILLAGE, BULELENG, BALI
}

\author{
Ketut Indra Purnomo, Komang Hendra Setiawan, \\ Made Kurnia Widiastuti Giri, IP Adi Wibowo \\ Ganesha University of Education, Singaraja, Bali
}

\begin{abstract}
BACKGROUND: Dengue haemorrhagic fever (DHF) remains a public health importance in the world. It causes hospitalization, death of patients, and high healthcare costs. This study aimed to describe factors associated mosquito larvae eradication and early management of DHF among poor community in Lokapaksa village, Buleleng, Bali.

SUBJECT AND METHODS: This was a qualitative study carried out in poor community in Lokapaksa village, Buleleng, Bali. The study subjects included 30 household heads and village heads. The data were colected by focus group discussion, indepth interview, and direct observation.

RESULTS: Outbreak of DHF occurred in Bali. In January 2016, 4 patients died from DHF. In 2015, according to the Provincial Health Office, there were 910 DHF cases, of which 262 cases occured in Buleleng, 245 cases occured in Gianyar districts. The response to new cases by clinics and community health centers was often late. Most of the villagers had low level of knowledge in mosquito larva eradication and early management of DHF. Mosquito larvae were found in about half of the houses surveyed. All of the household studied threw garbage in the backyard of houses. Health personnels had ever implemented fogging.

CONCLUSIONS: The villagers had low level of knowledge and poor practice in mosquito larva eradication and early management of DHF. Environment sanitation was poor. Health care system had late response in the incidence of new cases.
\end{abstract}

Keywords: Dengue Hemorrhagic Fever, mosquito larvae, larva eradication, early case management 